\title{
The importance of Self-efficacy and Resilience in the Learning Style of the University Student
}

\section{La importancia de la Autoeficacia y la Resiliencia en el Estilo de Aprendizaje del Alumno Universitario}

ESPERICUETA-MEDINA, Marta Nieves*†, SÁNCHEZ-RIVERA, Lilia, VILLARREAL-SOTO, Blanca Margarita and RAMÍREZ-PADRÓN, Marla Yudith

Universidad Autónoma de Coahuila, Faculty of Science, Education and Humanities

ID $1^{\text {st }}$ Author: Marta Nieves, Espericueta-Medina / ORC ID: 0000-0002-4924-4332, Researcher ID Thomson: T-15002018, arXiv Author ID Espericueta2018, CVU CONACYT ID: 372705

ID $1^{\text {st }}$ Coauthor: Lilia, Sánchez-Rivera / ORC ID: 0000-0001-9468-2599, Researcher ID Thomson: T-1404-2018, CVU CONACYT ID: 613195

ID $2^{\text {nd }}$ Coauthor: Blanca Margarita, Villarreal-Soto / ORC ID: 0000-0001-9314-8001, Researcher ID Thomson: 23572018, CVU CONACYT ID: 947979

ID $3^{\text {rd }}$ Coauthor: Marla Yudith, Ramírez-Padrón / ORC ID: 0000-0002-8023-2551, Researcher ID Thomson: ABE-28152020, CVU CONACYT ID: 633510

DOI: 10.35429/EJROP.2020.11.6.6.14

Received July 08, 2020; Accepted November 30, 2020

\section{Abstract}

The present research aims to identify the attributes that integrate learning styles with positive psychological functioning. The methodological value is explained from the application of two standardized tests with a Cronbach's alpha of 0.89 , made up of 102 variables in total; For this, an instrument composed of the self-efficacy section of the Schmeck learning styles inventory and the second the Merino positive psychological functioning scale was developed. I surveyed a total of 133 subjects. The statistical analyzes processed included the reliability and internal consistency test of the instrument; the selection of significant variables; descriptive analysis, measures of central tendency and variability; comparative analysis with Student's t test for independent samples, Pearson's correlation, integrational analysis from factorial and finally regression analysis. From the statistical results, it is highlighted that those students who lack a developed resilient ability have difficulty being selfeffective with respect to academic activities. Likewise, students who adequately reconcile their work, social and personal life, have high self-esteem, are creative, which allows them to be resilient and self-effective.

Learning styles, Self-efficacy, Resilience, Academic performance

\section{Resumen}

La presente investigación tiene como objetivo general identificar los atributos que integran los estilos de aprendizaje con el funcionamiento psicológico positivo. El valor metodológico se explica a partir de la aplicación de dos pruebas estandarizados con un alfa de Cronbach de 0.89, conformado con 102 variables en total; para lo anterior se elaboró un instrumento compuesto del apartado de autoeficacia del inventario de estilos de aprendizaje de Schmeck y la escala de funcionamiento Psicológico positivo de Merino. Se encuesto un total de 133 sujetos. Los análisis estadísticos procesados incluyeron la prueba de confiabilidad y consistencia interna del instrumento; la selección de variables significativas; análisis descriptivo, medidas de tendencia central y variabilidad; análisis comparativo con la prueba $\mathrm{T}$ de Student para muestras independientes, correlación de Pearson, el análisis integracional desde factorial y por último el análisis de regresión. De los resultados estadísticos se destaca que los estudiantes que carecen de una habilidad resiliente desarrollada tienen dificultad para ser auto eficaces con respecto a actividades académicas. Así mismo los alumnos que compatibilizan adecuadamente su vida laboral, social y personal, poseen una autoestima alta son creativos lo que les permite ser resilientes y auto eficaces.

Estilos de aprendizaje, Autoeficacia, Resiliencia, Rendimiento académico

Citation: ESPERICUETA-MEDINA, Marta Nieves, SÁNCHEZ-RIVERA, Lilia, VILLARREAL-SOTO, Blanca Margarita and RAMÍREZ-PADRÓN, Marla Yudith. The importance of Self-efficacy and Resilience in the Learning Style of the University Student. ECORFAN Journal-Republic of Paraguay. 2020. 6-11: 6-14

\footnotetext{
* Author Correspondence (mnieves@ uadec.edu.mx)

$\dagger$ Researcher contributing as first author.
} 


\section{Introduction}

For the student to develop in a holistic way, it is necessary to consider their psychological wellbeing in addition to identifying their learning style that impacts their academic performance. It is essential to respond to the demands of today's world, hence the importance of enhancing their skills that lead them to be successful in modern society.

The present research aims to know the attributes that make up learning styles and positive psychological functioning, in addition to showing the differences of opinion of the groups regarding academic performance. To understand how they interact with each other, and create a model that allows its implementation in the university educational area. The theoretical value consists of the contribution of authors who deal with topics about this topic. The methodological value is explained from the application of two standardized tests that make up an instrument where, from 102 variables, the study phenomenon is made explicit.

The working hypotheses:

H1. There are underlying elements between learning styles and positive psychological functioning.

$\mathrm{H} 2$. There is a difference of opinion according to the average of the students regarding resilience.

H3. There is a difference of opinion according to the average of the students with respect to selfefficacy.

Next, the axes that make up this research will be detailed.

During the last decades we have witnessed great changes such as technological, social, economic and political advances, which have echoed in the educational system.

Autonomous universities in Mexico use a humanist constructivist model based on competencies, practically the entire Mexican educational system is experiencing an effervescence by competencies.
For the student to develop in an integral way, the psychological well-being of the students must be considered, (Merino 2015) develops the scale of positive psychological functioning with the aim of measuring psychological well-being, through eleven psychological resources. Psychological resources are essential for the psychological well-being and physical and mental health of individuals.

In addition, it is necessary to identify the learning style of the students, it should be noted that Alonso, Gallego, and Honey (1995) affirm that the most accepted conceptualization about learning styles is that coming from James Keefe, director of the National Association of Directors of Secondary Schools in the United States of America, who affirms based on Witkin's contributions that learning styles are cognitive, affective and physiological traits that serve as relatively stable indicators of how students perceive interactions and respond to their learning environments. learning.

Recent research has not investigated the relationship between these two axes, however, the relationship between the complex variables of both axes has been studied, firstly, selfefficacy with academic performance and secondly, its relationship with the resilience.

\section{Learning styles}

This section presents introductory aspects and a bibliographic review from which it can be deduced that learning styles involve a whole set of exogenous characteristics such as pedagogical, social, contextual, and endogenous such as physiological, cognitive, affective, and Attitudinal which allow to understand how a student develops as a whole, and support in the determination of ways of learning. In addition, it should be noted that within a learning situation, the different ways in which the subject can learn must be considered, which entails aspects such as the set of methods, techniques, procedures, skills and actions that the individual uses during the learning process. learning to build your own knowledge. Sternberg (1999), considers that a style is a way of thinking. Not an aptitude, but rather a preferred way of employing the aptitudes one possesses, understanding that aptitude refers to how well someone can do something, while style to how someone likes to do something. 
For this reason, it is important to understand how students process information, when forming and using concepts, managing to understand, assimilate, structure and interpret the information to apply the contents and solve problems.

It should be borne in mind that one of the main objectives of the theory of learning styles is that education is inclusive by proposing an approach focused on the learning preferences of students, which is why it can be said that a student who is not aware of his own learning style, he may be unaware of the strategies that would allow him to guarantee an adequate acquisition of skills and knowledge, while a student who knows his learning style may experience an identification with the strategies that allow him not only meaningful learning but also be able to generate your own learning.

To understand the current relevance of learning styles, it is necessary to review the different definitions and categorizations that have been created regarding this construct since its appearance. With the objective of determining its importance in pedagogical practice.

Multiple authors have worked from different perspectives in defining the concept of learning styles. In the first place, there is Herman Witkin considered as the father of the cognitive style who was a cognitive psychologist in the fifties, who first coined the term cognitive styles, defining it as the way in which the human being perceives, processes, encodes and retrieves information. (Cabrera and Fariña, 2005).

Iriarte Diaz-Granados (2000), comments that Witkin distinguished two cognitive styles in the first place the independent field style in which individuals do not need institutions to solve situations, presenting a better orientation and counting on a greater number of internal references . On the other hand, the fielddependent style in which people interpret what they observe, and have the need for references or contextual elements to orient themselves, depend on the institution and need keys to orient themselves, and they cope easily with social content .
There are multiple models that have emerged for the classification of learning styles, therefore, in consideration of the theories that address the subject, a classification of the most relevant positions on said construct will be made.

One of the most relevant models is the one designed by David Kolb, this author affirms that he emphasized that experience is the basis of learning and the way in which information is perceived and processed. His theory is known as the learning wheel in which a cycle of four different phases occurs, concrete experience, reflective observation, abstract conceptualization and active experience. Kolb (1974), identified four learning styles: divergent, assimilative, convergent and accommodating, which can be identified from a measurement instrument designed in 1984, called the Learning Style Inventory (LSI),

It should be noted that the model used in the present research is the model of Ronal Schmeck who states that four factors or scales are fundamental to measure learning styles: deep processing: it requires reflection, it is abstract, logical and theoretical, elaborative processing: It also requires reflection, however, it is experimental and self-expressive, data retention: it is oriented towards the retention of information units necessary to successfully perform multiple-choice tests, and study method: it is composed of those skills that are applied when a topic is studied, for example, the use of underlining, the collection of notes, the ordering of notes, etc. (Ruiz et al., 1996).

\section{Positive psychological functioning}

Positive emotions are an important factor in having a healthy lifestyle, as well as the development of well-being and feeling happy, because they play a protective role in the face of adverse situations. Seligman (1999) says that Positive Psychology is the scientific study of the optimal functioning of people, it aims to discover and promote the factors that allow people and communities to prosper.

Positive emotional experiences have an effect that accumulates over time and expands the amount of adaptive resources of individuals. 
García Alandete (2014), affirms that a healthy, quality, creative, productive and selffulfilling life, the aspiration of every individual and every society, is associated with a certain lifestyle, with life satisfaction, with psychological well-being, with the experience of positive emotions and happiness. Selfacceptance: related to the fact that people feel good about themselves, are aware of their limitations, have positive attitudes towards oneself, is a fundamental characteristic of positive psychological functioning.

Positive psychological functioning arises from the union of studies on the functioning of psychological processes and emotional wellbeing. Psychological resources can be defined as the entities that people value for themselves or that serve as means to achieve a desired end. They can be objects, such as having a house; personal characteristics, whether physical, such as health, or psychological, such as self-esteem; conditions, such as having a certain educational level, having a job or being married, and energies such as time, money or knowledge (Hobfoll, 1989, 2002, 2010).

Merino (2015), develops the scale of positive psychological functioning with the objective of measuring psychological wellbeing, through eleven psychological resources. Psychological resources are essential for the psychological well-being and physical and mental health of individuals. Within the psychological resources proposed by Merino, there are resilience, optimism, enjoyment, which refer to aspects related to how to face a problem, the attitude and the ability to maintain a mentality of interest and enthusiasm towards activities carried out.

Merino (2017), conducted an investigation on Positive psychological functioning and its relationship with educational level, the Merino and Private scale (2015), and the Satisfaction with Life Scale (SWLS) (Diener et al., 1985) were applied. It is made up of 5 items Likert-type scale that emphasizes how happy or unhappy a person perceives habitual circumstances of their life. The sample was made up of 2902 participants representative of the Spanish population with ages ranging between 17 and 55 years.
It was found that people with a higher educational level also have more psychological resources such as curiosity, creativity, mastery of the environment, autonomy or vital purpose. Therefore, it affirms that both the well-being and the psychological resources increase as the educational level increases, but this increase declines in people who have completed undergraduate studies, but not undergraduate studies.

Llauradó, E. V., \& Riveiro, J. M. S. (2020). They mention that there are statistically significant correlations between stress, resilience and satisfaction. On the other hand, in their study they found that the regression analyzes show that there are variables, mainly of resilience, that enter the model in a statistically significant way, while other variables, such as disability or type of disability, do not influence this prediction.

Atencia, D. J., Plaza, M. T., \& Hernández, H. E. (2020). They mention that resilient students would adapt effectively facing situations of physical and emotional exhaustion, they would show the ability to avoid situations of apathy, distancing, loss of competence and academic effectiveness, since they have the power to measure their own abilities in the face of challenges and demands both academic and psychosocial that assume the burden inherent in the nature of academic activity.

Chuquillanqui Verastegui, G. C., \& Villanes Cancho, J. P. (2020). In their work they found that there is a significant relationship of resilience with the stress coping styles of the university student.

\section{Methodology to be developed}

The focus of this research is quantitative since: The order is rigorous, although of course we can define some phase. It starts from an idea that is being limited and, once defined, objectives and research questions are derived, the literature is reviewed and a framework or a theoretical perspective is built. From the questions hypotheses are established and variables are determined; a plan is drawn up to test them (design), variables are measured in a given context; 
The measurements obtained are analyzed using statistical methods, and a series of conclusions are drawn regarding the hypothesis or hypotheses. (Hernández, Fernández and Baptista, 2014, p. 4-5)

Due to its design, it is transectional or transversal because it is an investigation that collects data in a single moment. Its purpose is to describe variables and analyze their incidence and interrelation at a given moment. (Hernández, Fernández and Baptista, 2014, p. 154)

Due to its scope, it is an exploratory research, because it examines a little-studied topic or research problem, descriptive because it describes the phenomenon under study and correlational because it establishes relationships between the variables without specifying a sense of causality. (Hernández, 2014, p.90)

The instrument is developed which is composed of two standardized scales, the first is the Inventory of Learning Styles (ILP-R) by Ronald Schmeck in its standardized version for the Spanish population in 1996 by Manuel Esteban, Cecilia Ruiz and Fuensanta Cerezo. The second is the Merino positive psychological functioning scale carried out in 2015 and validated in the Mexican population the same year, the pilot test is carried out which allowed making adjustments at the linguistic level in the items, the final application of the questionnaire is applied in a single session.

To give validity and reliability to the data and explanations of the present investigation, an instrument is made that consists of 9 signal variables and 103 of the phenomenon. Of which the average variable belongs to the axis of academic performance, 33 variables are of positive psychological functioning and 69 variables of Learning styles.

The signal variables are Age, Gender, City, State, Educational Institution, Study career, Semester, If you currently work, If you have worked before. Academic performance is measured with the general average variable obtained so far. The positive psychological functioning scale is made up of 33 Likert-type items that are grouped into 11 dimensions, each one made up of three questions. (autonomy, resilience, self-esteem, life purpose, enjoyment, optimism, curiosity, creativity, humor, mastery of the environment and vitality).
The Learning Styles scale is made up of nine subscales, divided into two groups, the first one measures aspects related to personality and attitude, and the second one measures cognitive aspects and mental processes. For this research, the four subscales belonging to the personality aspects are applied, which include the Learning Styles based on global self-efficacy, motivation, academic self-esteem and self-affirmation, it consists of 69 questions.

\section{Results}

The instrument's reliability data are obtained from Cronbach's alpha coefficient with an integrated scale with a value of 0.89 that shows an internal consistency of the scale.

\section{Descriptive Analysis Frequencies and Percentages}

Out of a total of 133 subjects, the ages of the selected sample range from 17 to 54 years, of which the majority are women (n: $98,73.7 \%$ ) and to a lesser extent men (n: 35, 26.3\%).

As for their place of origin, $54.9 \%$ are from the state of Coahuila and $36.1 \%$ from the State of Tabasco, $8.6 \%$ from the State of Mexico. being the majority inhabitants of the city of Saltillo 52.6\%.

Regarding the educational institution attended by the Faculty of Science, Education and Humanities, it has $33.8 \%$ followed by the Autonomous University of Tabasco with $39.1 \%$, the career with the highest proportion of students is $35.3 \%$ the Bachelor of Science in the education of the, followed by $13.5 \%$ of the Bachelor of Economics and $10.5 \%$ of the Bachelor of Nursing. With a grade point average between .50 and 100 , highlighting that $52.9 \%$ of respondents average grades from 90 to 100 while $47.1 \%$ report grades lower than 90 .

The variable you currently work shows that $73.7 \%$ of the surveyed students do not work at present, while $26.3 \%$ continue to work. Highlighting that $72.9 \%$ of those surveyed have worked before while $27.1 \%$ have not had work experience. (see annexes 4 , tables 2 to 11 ) 


\section{Comparative Analysis Student's $\mathbf{t}$ for independent samples}

In order to compare samples through their arithmetic means and find significant differences depending on the average, two comparative analyzes are shown below with the student's $t$ test for independent samples with a probable error value less than 0.001 ( $p<0.001)$, the statistical values that appear in this analysis are the sample values of each analysis group (Mean $(\mathrm{X})$ of the groups), the t-test value (t-value), the degrees of freedom (df) and the probability of the error level $(\mathrm{p})$.

For the first comparison, the variables of Positive Psychological Functioning and Learning Styles are taken as the average grouping variable and as contrast variables.

From the analysis in the contrast reading, it is observed in terms of the Average variable that the global self-efficacy variable, in its three grouping variables, organizational self-efficacy, thinking and data retention, belonging to the Learning Styles axis, presents a significant difference in consideration of the average of the students who have an average higher than ninety-five and the students with an average lower than ninety-five. Therefore, it is inferred that students with a greater capacity for global self-efficacy with respect to academic activities obtain high averages, unlike students with a lower capacity for self-efficacy.

Regarding the average variable, it is observed that the resilience variable, belonging to the axis of positive psychological functioning styles, presents a significant difference in consideration of the average of the students who have an average higher than ninety-five ( $\overline{\mathrm{x}}=$ 4.72) and students with an average lower than ninety-five $(\overline{\mathrm{x}}=4.06)$. Therefore, it is inferred that the students who have developed their resilience ability obtain higher averages than the students with less ability to face adversity.

Therefore, it is inferred that students who have developed their resilience capacity obtain higher averages, unlike students with less resilience capacity.

\section{Integrational Analysis Exploratory factorial}

From the total of 102 variables used, an underlying structure was obtained according to the criterion of the 4-factor sedimentation graph. In order to establish the underlying structure of the study phenomenon, an exploratory factor analysis is processed in the SPSS program using the principal components method and with varimax rotation. The Kaiser-Meyer-Olkin sample adequacy test shows a level of adequacy .705 , in addition, the Barttlet sphericity test rejects the null hypothesis for obtaining a critical level (Sig) <0.05; which shows that the correlation matrix is adequate for factoring.

According to the sedimentation graph, it is observed that the inflection point is at factor 4 . We work with the r-squared method with a varimax rotation with an $r \geq 0.28$.

The first factor, positive psychological resources, explains $18.68 \%$ of the common variance of the studied phenomenon; It is made up of the variables resilience, optimism, vitality, life purpose, autonomy, creativity and mastery of the environment belonging to the axis of positive psychological functioning, and by the variables motivation: effort and academic selfesteem of the axis of Learning styles.

When the subject is able to overcome the difficulties that arise, in him there is optimism when facing academic situations, and also enjoy carrying out the activities that allows him to be autonomous, master the surrounding context and feel motivated. which he demonstrates through the effort he makes in his academic activities. It is inferred that students who have a developed resilient ability have the facility to think optimistically and see the good side of things, which allows them to be sure of themselves, enjoying their school life by having a balance in different contexts, the social, family and academic, and all of this is reflected in the effort they show to achieve their goals.

The second factor called School selfefficacy, which explains $10.05 \%$, is made up of the variable domain of the environment of the axis of positive psychological functioning, and by the variables of Learning styles: Organizational self-efficacy, thinking and data retention, as well as by the variables, selfesteem and academic motivation and effort. 
When the subjects are able to dominate the environment that surrounds them, they balance their activities which allows them to be self-sufficient at the organizational, thinking and data retention levels, which increases their selfesteem and motivation with respect to academic responsibilities. It is inferred that students who can balance different social, family and school contexts, use a learning style based on selfefficacy at a global level in their school activities, which allows them to have a high academic self-esteem.

\section{Analysis \\ Multiple Linear Regression}

A linear regression analysis is performed to identify the attributes with predictability of academic performance, the average variable is used as the dependent variable and as independent variables 12 variables of the axis of Learning styles and of the axis of positive psychological functioning that showed difference of opinion with respect to the average in the comparative analysis.

The explanation model obtained a structure whose significance of $\mathrm{F}$ is less than 0.05 , therefore the model is good to explain the dependent variable. The R-squared is 0.362 , which indicates that the model explains $36 \%$ of the variance of the dependent variable, almost half of the average is explained by the set of independent variables.

With respect to the significance of the $\mathrm{T}$ test, the set of variables self-efficacy of thought and resilience do explain the average because the significance is less than 0.05 . The dependent variable that most explains people's opinion regarding the average is the self-efficacy of thinking, it can be read that the variable selfefficacy of thinking predicts the academic average. The next variable that explains the most is resilience as a predictor variable of the academic average.

It is inferred that the variables selfefficacy and resilience are therefore predictors of academic performance because they directly impact the average obtained. Therefore, it is deduced that students with ability in the psychological resource resilience, who also use the self-efficacy learning style, are those who have academic success.

\section{Conclusions}

It is concluded that students with a higher capacity for self-efficacy with respect to academic activities obtain high averages, unlike students with a lower capacity for self-efficacy.

It is denoted that the students who have developed their resilience capacity obtain higher averages, unlike the students with less resilience capacity.

It is concluded that students who lack a developed resilient ability have difficulty maintaining a sense of humor with regard to academic activities because they are not selfsufficient and do not control their emotions, which is reflected in their academic efficiency. Likewise, students who are nervous distrust their own abilities and therefore request support which allows them to be more self-efficient in their school activities.

It is concluded that students who are selfeffective in carrying out their academic activities develop divergent thinking that allows them to find different solutions to the problems that arise, they can also adequately reconcile their work, social and personal life, they have high self-esteem It allows them to clearly express their opinions and feelings.

It is denoted that the more importance is given to self-efficacy, the higher the average.

It is denoted that the higher the level of resilience, the greater the average obtained,

It is concluded that if the self-affirmation variable increases, the average increases.

In conclusion, it is said that the variables self-efficacy and resilience are therefore predictors of academic performance because they directly impact the average obtained. Therefore, it is deduced that the students with the greatest ability in the psychological resource resilience, who also use the self-efficacy learning style, are those who are academically successful. 
Therefore, it is proposed to develop a pedagogical model that allows changing the paradigm by adapting the educational context to expand learning possibilities, allowing to potentiate psychological resources such as resilience, as well as learning styles based on global self-efficacy in university students., so that they are able to unfold their potential and obtain academic success.

Regarding the limitations of this research work, it is noted that the sample used is not large enough to support more forceful conclusions, which is why the results cannot be generalized to broader populations.

\section{References}

Atencia, D. J., Plaza, M. T., \& Hernandez, H. E. (2020). Resiliencia, burnout y fracaso académico en estudiantes de Ingeniería. Revista ESPACIOS, 41(11).

Cabrera Albert, J. S., \& Fariñas León, G. (2005). El estudio de los estilos de aprendizaje desde una perspectiva vigostkiana: una aproximación conceptual. Revista Iberoamericana De Educación, $\quad 37(1), \quad 1-10$. https://doi.org/10.35362/rie3712731

Chuquillanqui Verastegui, G. C., \& Villanes Cancho, J. P. (2020). Resiliencia y afrontamiento del estrés en estudiantes de trabajo social de una universidad estatal de Huancayo-2019.

Garcia-Alandete, Joaquín. Psicología positiva, bienestar y calidad de vida. En-clav. pen [online]. 2014, vol.8, n.16, pp.13-29. ISSN 2594-1100.

Hobfoll, S. E. (1989). Conservation of resources: A new attempt at conceptualizing stress. American Psychologist, 44(3), 513-524. http://dx.doi.org/10.1037/0003-066X.44.3.513 Hobfoll, S. E. (2002). Social and psychological resources and adaptation. Review of General Psychology, 6(4), 307-324. http://dx.doi.org/10.1037/1089-2680.6.4.307

Hobfoll, S.E, (2010). Conservation of resource caravans and engaged settings. Journal of Occupational and Organizational Psychology, 84, 116-122. http://dx.doi.org/10.1111/j.20448325.2010.02016.x
Iriarte Diaz-Granados, F., Cantillo, K., y Polo, A. (2000). Relación entre el nivel de pensamiento y el estilo cognitivo dependenciaindependencia de campo en estudiantes universitarios. Psicología Desde El Caribe, O(5), 176-196.

Kolb, D., Rubin, I., \& McIntyre, J. (1977). Psicología de las Organizaciones: Problemas Contenporáneos (Primera ed.). (L. Brignardello, Trad.) México: Prentice-Hall Hispanoamericana.

Kolb, D., Rubin, I., McIntyre, J., James, M., \& Brignardello, L. (1974). Psicología de las Organizaciones: Experiencias. Mexico: Prentice Hall Hispanoamericana.

Llauradó, E. V., \& Riveiro, J. M. S. (2020). Resiliencia, satisfacción y situación de las familias con hijos/as con y sin discapacidad como predictores del estrés familiar. Ansiedad y Estrés.

Merino Rivera, M. D., Privado, J., Díaz, E., Rubio, S., y López, M. I. (2017). Funcionamiento psicológico positivo en España: ¿existen diferencias en función del nivel educativo? Revista de Estudios e Investigación En Psicología y Educación, 07, 118. https://doi.org/10.17979/reipe.2017.0.07.3000

Merino, M. D. M. D., Privado, J., Gracia, Z., Díaz, E., Rubio, S., López, I., Dolores Merino, M., y Privado, J. (2015). Funcionamiento psicológico positivo. Evidencia para un nuevo constructo y su medición. Salud Mental, 38(2), 109-115. https://doi.org/10.17711/SM.01853325.2015.015

Merino, M. D., Privado, J., y Gracia, Z. (2015). Validación mexicana de la Escala de Funcionamiento psicológico positivo. Perspectivas en torno al estudio del bienestar y su medida. Salud Mental, 38(2), 109-115. https://doi.org/10.17711/SM.01853325.2015 .015

Ruiz, J., Cerezo Ramírez, F., \& Esteban Albert, M. (1996). Validación del cuestionario ILP-R, versión española. Anales de Psicología, 12(2), $133-152$.

Sampieri, H. (1998). Metodología de la investigación. Mg Graw Hill. 
Sampieri, R. H., Collado, C. F., María, D., Lucio, B., Valencia, S. M., Paulina, C., yTorres, M. (2014). Dr. Roberto Hernández Sampieri. Mc Graw Hill.

Schmeck, R. R. (n.d.). Improving Learning by Improving Thinking.

Seligman (1998). “The President's address. APA Annual Report", en American Psychologist, núm. 54, 1999, pp. 559-562; M. E. P. Seligman, "Positive Health", en Applied Psychology, núm. 57, 2008, pp. 3-18.

Sternberg, R. J. (1999). Estilos de pensamiento. Barcelona: Paidós 